\title{
Volunteering for Development within the New Ecosystem of International Development
}

\author{
Jo Howard and Danny Burns
}

\begin{abstract}
This article explores the ways in which volunteering for development is changing in the context of the shifting wider ecology of international development. It draws on a two-year, action research project into the value of volunteering undertaken by volunteer researchers in Kenya, Mozambique, Nepal and the Philippines. The article frames this research and the articles in this IDS Bulletin in the key debates past, current and emerging - around the role, identity and value of volunteers in development processes. It identifies critical characteristics of effective volunteering for development as: the insider-outsider relationship; participatory processes, long-term programming; and a sustained focus on the poorest and most marginalised. The authors draw attention to the relevance of volunteering to achieving the Sustainable Development Goals (SDGs), and call for better understanding of indigenous informal volunteering and how 'outsider' volunteers can support it.
\end{abstract}

\section{Introduction}

This article explores the ways in which volunteering for development is changing in the context of the shifting wider ecology of international development. It draws on a two-year, four-country action research study into volunteering carried out by the Institute of Development Studies (IDS) and Voluntary Service Overseas (VSO) (Burns et al. 2015). The article sets out to frame this research and the articles in this IDS Bulletin in the key debates - past and emerging - around the role, identity, and value of volunteers in development processes.

Volunteering for development $(\mathrm{VfD})$ has been profoundly influenced by the legacy of colonialism that created and continues to shape development policy and practice today. In order to understand international volunteering today, we need to understand how it has evolved over time through its relationship with international development (Baillie Smith and Laurie 2011). International development, as it has emerged over the decades since many countries achieved independence from colonial rule, has been marked by the phases of modernisation, liberalisation and structural adjustment (Perold $e t$ al. 2013). Yet, discourses of development as freedom, as coined by Sen (see Perold et al. 2013) have chimed with more radical discourses of development such as autonomy, collective empowerment and postdevelopment (Esteva 2014; Escobar 2011).

International volunteering needs to be situated in this complex and contradictory setting. Ongoing neocolonial framings continue to cast 'the South' as tragic and in need of rescue (Said 1978; Wehbi, Elin and El-Lahib 2010). Heron (2007) identifies a neocolonial urge in development work that situates the Northern development worker as saviour, and positions the host organisation and people as lacking, and whom the heroic subject from the 'developed' world is to save. At the same time, the professionalisation of the non-governmental organisation (NGO) and 'voluntary' sectors puts increasing pressure on international volunteers and on volunteering for development organisations to be competitive, to engage in partnerships with corporations, framing volunteering more as a business strategy or professional development than as altruism.

Yet humanity, mutual learning, empowerment, global citizenship, social justice and community building are also goals of international volunteering, emanating from across the different and sometimes conflicting or contradictory development approaches and agendas (Baillie Smith and Laurie 2011; see 


\section{Development approaches}

Modernisation

Basic needs

Participation

Governance/civil society

NGOisation/professionalisation

Rights-based development

'Niche' paradigms (e.g. fair trade, ethnodevelopment, faith-based development)

\section{Volunteering goals}

Benevolence and service

Technical assistance/knowledge transfer

Mutual learning

Citizenship and empowerment

Professional development

Global citizenship, social justice, personal development and community building/strengthening

Source Baillie Smith and Laurie (2011: 549).

Table 1). For many, international volunteering enables cultural exchange which promotes intercultural understanding (Lough et al. 2011). At best, volunteering is about fostering 'insideroutsider' two-way relationships between volunteers (international or national) and partners/community members. The Valuing Volunteering research found that:

Volunteers have the ability simultaneously to be on the 'inside' and the 'outside' of a community in a way that few other development practitioners are. The combination of insiders who have access to strong local networks, and outsiders who come with access to skills and external networks, allows effective and culturally sensitive innovations to take place (Burns et al. 2015: 32).

These are relationships which strengthen local capacities and networks, and are likely to foster innovation at a local level (Burns et al. 2015).

Lopez Franco and Shahrokh's (this IDS Bulletin) timeline charts milestones in international volunteering and shifts in development paradigms over the decades since 1950. They identify a growing acknowledgement of the role of international volunteering as an approach to development (1990s), but also growing pressure to justify its value for money (2000s). We cannot read these genealogies as linear; there is movement back and forth as old ideas re-emerge, and 'particular practices are privileged, re-named or reconfigured' (Baillie Smith and Laurie 2011: 549). There is also nonlinear movement between development discourses and ideas about international volunteering which reinforce each other, so that NGOisation in the North breeds a need for greater professional skills in the South, which is responded to by international volunteers who are themselves responding to the pressure they feel to professionalise and improve their career prospects (ibid.: 50). At its worst, this can be what Devereux (2008: 358) calls 'a self-serving quest for career and personal development on the part of well-off Westerners'. Certainly, international voluntary service is shaped by discourses of development, aid and trade, and these challenge the potential of volunteers to contribute significantly to development (Perold et al. 2013: 193).

So, in order to understand the value of volunteering in development, we need to look both outwards and inwards. While acknowledging and critiquing the structural drivers and power relations that perpetuate neocolonialism and global injustice, and recognising that international volunteering must be shaped to some extent by these structures, we can also look more closely at the detail of what happens when volunteers engage with people, especially people who are living in poverty and marginalisation.

International volunteering is an approach that involves bringing people from different cultural settings together. In some contexts, it has constituted 
a form of solidarity - raising the visibility of the local situation, or 'accompanying' people who are at risk by living alongside them, for example with displaced indigenous communities in Guatemala in the 1990s (Henderson 2009). In others it has provided a challenge to the social norms of both international volunteers and the communities that they are placed amid. Many placements become formative experiences for volunteers who learn about other cultures and take new values and solidarities into their later work (Devereux 2008). Some argue that the intercultural encounter, especially in the international development framing, reaffirms our cultural identities, rather than unsettling them (Jefferess 2012), but Hopkins et al. (2015) find it can be a productive unsettling, and that capturing the benefits of this unsettling is a methodological issue.

\section{This article draws on the Valuing Volunteering} research to explore the contribution to development of a particular methodological approach to international volunteering - a participatory bottom-up approach, and considers how this approach itself may prefigure ways in which volunteering can be researched and volunteering itself can be constructed.

\section{Volunteering in the new ecosystem of development}

The research undertaken by VSO and IDS including the Valuing Volunteering project, a review of VSO's Participation and Governance thematic area of work, and this IDS Bulletin itself - is part of an inquiry that wishes to understand the contribution of volunteering to development, and the place and value of volunteering in the current and future development 'ecosystem' - by which we mean a set of inter-related and inter-dependent elements which interact to comprise the whole system of development. Each element has its place and none can fulfil its function without the others. The research has attempted to be deeply participatory in approach, employing participatory systemic inquiry (PSI) and systemic action research (SAR) as methodologies guiding the inquiry (see Hacker this IDS Bulletin, and the Editorial, this IDS Bulletin).

\section{The approach has attempted to challenge} and interrogate 'Northern' assumptions about volunteering, and to find out what kind of volunteering, in what circumstances, makes a positive difference. The shifts that are taking place in the global economy and the development ecosystem have impacted significantly on volunteering, causing a shift in the volunteering paradigm away from the generic and/or longer-term model towards shorter placements for skills transfer. This articulates with what many argue has been a shift towards the commodification of volunteering. In many ways, the rolling out of neoliberalism in the form of structural adjustments (macroeconomic balancing and public sector spending cuts) and the accompanying rise of governance as a new approach to public sector management, ushered in a larger but instrumental role for non-state actors in the provision of public services. NGOs and volunteers flooded in to bring their labour and technical knowledge to produce or to shore up dwindling public services (Banks, Hulme and Edwards 2015). But the consequence is that volunteering can become constructed as a means to deliver services more cheaply and effectively, and to fill the gaps as public services are reduced.

Another aspect of this process has been the depoliticisation of poverty, since development interventions increasingly became understood as technical fixes, development workers as anti-poverty technicians, and volunteers as technical experts. At the same time, the notion of rights as underpinning people's relationship to the state became eroded as citizens were increasingly cast as consumers of services rather than as rights-bearers (Cornwall 2000; Cornwall and Gaventa 2000).

The volunteering trajectory is bound up in this process of individualisation and marketisation of state-society relations. Anheier and Salamon (2001: 3) found in cross-national research conducted over a decade ago, that trends of individualisation and secularisation were redefining volunteering, to the extent that 'as a phenomenon, it is today ever less linked to religion, notions like "service to the nation" and traditional expectations, and tied more to specific needs, self-interest and greater individual choice'. Some also argue that the rise in youth volunteering is part of an attempt by Northern governments to address their own rising youth unemployment rather than emanating from a sense of responsibility and service to developing nations (Baillie Smith and Laurie 2011). Ongoing austerity policies in the North and South encourage volunteering as a source of labour especially in community-based social services which are worst affected by public sector cuts (Andres and Round 2015). This has led to what some describe as 'responsiblisation' (Taylor 2011) whereby community volunteers end up taking on responsibilities for providing services to the poorest and most vulnerable people, for whom the state has a duty of care. 
In recent years a range of new expressions of volunteering for development have emerged, which we briefly introduce here:

- The emergence of large-scale national volunteering schemes;

- Experts replacing generic unskilled volunteers;

- The resurgence of short-term volunteering;

- The shift away from volunteering as an end in itself;

- An emerging engagement with volunteering as community action.

\subsection{Connecting international volunteers to national volunteering schemes}

The emergence of large-scale national volunteering programmes has coincided with a backlash against a more paternalist internationalist volunteerism. This has led to a model of international engagement which is more closely rooted in partnership with national agencies. VSO also works with governments to support and advise them in setting up such programmes. As a result, international volunteers (North-South and South-South) increasingly work alongside national volunteer schemes which are deploying large numbers of people with a lot of reach.

However, while there is an obvious affinity to be built on that draws international VfD organisations to work with national volunteering organisations, this partnership is not unproblematic. This is because the aims of these organisations may not align with those of international volunteering organisations such as VSO. We encountered this disjuncture in Ghana, for example. Here the national volunteer programme was strongly focused on large-scale agricultural development. The aim was in part to re-incentivise people to work in rural livelihoods but it was structured as large-scale farming units. These were initially demonstration projects staffed by volunteers with a view to a much larger national rollout. A systemic analysis revealed that while this had the potential to impact on national economic growth it was likely to undermine local livelihoods for the poorest and most marginalised. The underpinning aim seemed to prioritise nation-building linked to economic growth, rather than attention to poverty.

In Rwanda on the other hand, personal development and active citizenship are the focus of the new national service programme for students in higher learning institutions and universities (launched in October 2014). A significant motivating factor for governments has been the desire to harness youth energy for nation-building activities, while at the same time constructing a national idea and practice of active citizenship. In Kinyarwanda, the national service is known as Urugerero, and revives an ancient Rwandan custom where young men left their families for national service. It complemented Itorero - training for young people on patriotism, values, resilience and determination. The new national service programme aims to build these values and promote national volunteering (Howard, Lewis and Burns 2015).

These examples suggest that partnerships between international VfD organisations and national volunteer programmes cannot assume shared values on the basis of a shared approach - working through volunteers. In our view it is important that values are aligned in volunteering partnerships. Moreover, it is critical to think through how to connect up and integrate effectively different kinds of volunteers. When a VfD organisation is working through short-term, long-term, youth, national, corporate, political, South-South and North-South volunteers, there is a more compelling need for a systemic overview which enables an understanding of the entry points at which different kinds of volunteer can add the most value. This requires strong oversight and systemic research skills in the country office:

So, someone is responsible for youth volunteers, someone for diaspora volunteers, someone for long-term volunteers, someone for national volunteers... so if you want to know what is happening with secure livelihoods you have to go and talk to each of these people... what we need is someone with oversight (interview with VSO staff, Howard et al. 2015).

\subsection{Shift to strongly technical focus from volunteering agencies}

As argued above, the international volunteering responses to the changing development paradigms have ranged from the technical assistance mode (typical during the modernisation development era) through to greater emphasis on learning and empowerment, on personal development and on global citizenship) - see Table 1.

As stated earlier, these genealogies are not linear. In fact, we are now seeing a growing re-emphasis on skills transfer, partly as a response to critiques of international volunteering as paternalist and of gap-year unskilled volunteers as self-seeking, but also 
as a mechanism for deploying a global workforce (Jones 2008). This shift is not unproblematic, since experts from the North (who happen to be volunteers) come in with new curricula, educational tools, livelihood programmes, etc which may not be appropriate to local circumstances or reflect local values. Furthermore, it is sometimes difficult to match the demand for a skill to an available volunteer. This creates the risk of allowing volunteer 'offer' to drive placements, which can lead to host organisations agreeing to a placement because a volunteer is available and they value the status and spin-offs of hosting an international volunteer but do not necessarily need or value the particular skills that they bring.

Analysis by host organisations and volunteers involved in the Valuing Volunteering research suggests that there is appetite for external knowledge, for different perspectives and energy, but also a deep frustration with the one-way nature of many of these interventions. The challenge is to create space and processes that allow local people to engage with the new perspectives and knowledge on their own terms, and explore together how it can be integrated into what they do well already (see Lewis, this IDS Bulletin). This points towards the need to embed volunteering in co-creative methodologies which enable different forms of knowledge to be valued and to interact. The paradigm of volunteering that is consistently highlighted as important in the Valuing Volunteering research is that of mutual learning, which we would argue with reference to Table 1 - needs to underpin all paradigms of volunteering rather than be seen as a separate approach. The research suggests that for any volunteering initiative to be successful (short or long term, international or national) it needs to be underpinned by principles and methodologies of mutual learning.

\subsection{Resurgence of more short-term forms of volunteering}

Volunteering for young people abroad can be unreflective and an enactment of privilege (Jefferess 2012), and this is intensified as placements become shorter: as the trip length decreases, the volunteering placements are designed more for the convenience of the volunteer rather than to support local community needs. In 2006, VSO warned of the risk that the proliferating gap-year programmes might become a new form of colonialism, reinforcing an attitude of 'it's all about us' by their emphasis on shortterm 'helping' over learning', (Lopez Franco and Shahrokh 2012). Despite this, major programmes such as the UK's International Citizens Service have signalled a resurgence of short-term volunteering, and there is continued growth of what has been called voluntourism - where young people often pay their own way to work in communities abroad, perpetuating 'a popular humanitarian gaze that contributes to recurring geopolitical discourses of North-South relations that naturalise political, economic and social inequality' (Mostafanezhad 2014: 112). 'Corporate volunteering' has also emerged in the development landscape as a response both to the pressures for corporate social responsibility and the economic crisis which has brought new actors into the development world as a way of escaping from redundancies and a depressed labour market in the North (Baillie Smith and Laurie 2011).

This approach to volunteering is re-asserting a top-down approach. Corporate volunteers are able to provide a certain number of hours of financial advice, or hours of IT programming support, or send a water engineer. Certainly these may be useful contributions, but they are simultaneously re-enforcing the idea of a oneway relationship and disingenuously promoting values of benevolence and global citizenship while in fact privileging the professional development of workers from the North. It is worth noting as an aside that corporate volunteering also brings in its wake the problem of branding, which can legitimise practices that VfD organisations might have fundamental disagreements with. The entry of corporate volunteers into the development setting can also reinforce global inequalities instead of promoting global solidarities, since it often assumes 'communities and mobilities for the volunteer in ways that privilege individual choice and autonomy over complex political contexts' (Baillie Smith and Laurie 2011: 555).

\subsection{Shift away from volunteering as an end in itself}

Organisations such as VSO began to shift their focus from volunteering as an intrinsically worthwhile activity towards volunteering as a way of achieving wider aims. With a new emphasis on volunteering for development they are articulating themselves as development organisations which achieve their aims through volunteering. This has not been unproblematic as to some extent the 'why volunteering' part of their message became obscured, raising questions about why they should be funded as opposed to long-standing development stalwarts with huge experience and infrastructure such as Oxfam and Action Aid. The Valuing Volunteering research was in part an 
effort to provide an evidence base for how and why volunteering can be a particularly strong vehicle for development efforts.

\subsection{An emerging engagement with community volunteering}

The prevailing development view of volunteering as embodied in an individual volunteer from the global North has obscured existent ways in which local communities for centuries have devised self-help and mutual aid mechanisms. How best can 'volunteers for development' interact with the existing forms of community support and action? 'Volunteering' as a concept needs to be examined both in terms of how it links into informal community action, and in terms of the spaces it creates and/or engages with at the local level.

\section{Community action creates informal spaces and} networks into which external volunteers can step, and in which they can build relationships and support local groups. Using the vocabulary of social capital, we can say that volunteers from outside the community step into spaces where bonding social capital already exists, but to which they bring their own bridging social capital. This relational contribution is cumulative and less easily captured by linear and numerical forms of impact evaluation (Lough and Matthew 2013; Lopez Franco and Shahrokh, this IDS Bulletin). The international volunteer may act as a broker between the local group and resource holders: 'IVs may provide bridging social capital to organizations in lowincome regions of the world that may not be easily supplied by domestic volunteers. These linkages can help bridge the resource gap; connecting those in low-income countries with more powerful individuals and institutions in resource-rich countries' (Lough et al. 2011: 135).

However, they will also need to navigate politics as Picken and Lewis observe (this IDS Bulletin). In their analysis, the 'outsider' volunteer (whether international or national 'insider mediator') can offer neutrality, which can be a valuable asset for opening up new spaces of participation and which can have significant impacts on facilitating the entry of excluded groups. The volunteering space is therefore collaborative, informal, a space of relationships and of action. It is where volunteers work through 'doing together', creating what Aked (this IDS Bulletin) describes as 'safe interpersonal spaces for people to practise at making change happen'. It is mutable, a space in which trust needs to be built but in which the tensions created through inequalities of race, ethnicity, gender, class, caste, political affiliation, etc will also be present. The 'outsider' volunteer must therefore be able to navigate these tensions, and also to acknowledge their own positionality in this space, and the tensions that they bring to it. This calls for a good capacity for reflexivity and critical analysis, skills that can be nurtured through training in participatory methodologies (see Hacker, this IDS Bulletin).

On the side of partner organisations, in order for local participation and capacity to be fostered and sustained, a shift is also needed in how host organisations view themselves and how they are viewed by sending organisations. Host organisations need to recognise their own power and agency, and have to be more demanding of what they want from the relationship (Perold et al. 2013). Some authors have found that 'the international service experience might in fact serve to reinforce rather than challenge dependency relationships' and argue that volunteer and host organisations need to work together to build better understanding of how they might strategically use volunteers to break cycles of dependency (Perold et al. 2013: 188).

Yet this dependency argument is challenged by Aked (this IDS Bulletin) whose research finds that 'volunteer relationships built on informality, the act of doing together and networked reciprocity trigger wellbeing-enhancing experiences which support individual actors to do well and actors to do well together'. Long-term interventions rooted in capacity development allow communities to build the skills, knowledge, confidence, networks and so on needed to become independent, which means that longterm volunteering can actually reduce dependency, not create it. If Aked's argument is correct, then the contribution of volunteers could be a critical factor in bringing about sustainable positive changes in the lives of people living in poverty and marginalisation.

How are volunteers prepared and supported to work effectively in the volunteer space at community level? We are making the case here that 'outsider' volunteers need to have community development skills and a high level of critical awareness, and these skills need to be prioritised by international volunteer cooperation organisations (IVCOs) (see also Simpson 2004). Important here are 'the relational processes that link the placement of a volunteer to effective social action' (Aked, this IDS Bulletin). The Valuing Volunteering research tested out the contribution that training volunteers in the use of participatory methodologies can bring to this process. 


\section{The landscape continues to change}

As we have seen, volunteering trends have shifted substantially over the past decade or so. The external environment continues to change and is likely to trigger further shifts in volunteering. We now outline some of these trends.

\subsection{Further austerity and cutbacks in public services}

One of the features of the current political landscape is continued cutbacks in public services and in some countries (as we saw in Kenya), a strongly individualist culture. The continued rolling back of the state in the North as well as in the South further entrenches the tendencies discussed earlier for volunteers to step in and fill the gap as the state retreats. With pressure and conditionalities imposed by international financial institutions to reduce public spending, voluntary action is less likely to take the form of advocacy and more likely to focus on providing the services that are lacking. Yet it may also be that volunteers during the coming period may be able to sustain the beacon of collectivism and continue to model it for future generations, as suggested by the emergence of community health workers as a force for solidarity and social justice in Latin America (Perez and Martinez 2008). But in this continued climate of austerity, how volunteers are recompensed by international non-governmental organisations (INGOs) and donors will need to be carefully thought through to avoid undermining solidarity action and distorting volunteer efforts (see Lewis, this IDS Bulletin).

\subsection{The Sustainable Development Goals}

Perhaps the most fundamental shift that will take place in the global landscape is the introduction at the start of 2016 of the new Sustainable

Development Goals (SDGs). There are a number of key aspects of this framework and assumptions that underpin them which will be crucial to the debates about the role of volunteering.

\section{The SDGs are universal}

This means that the SDGs will apply to all countries, and the focus of development will be on people living in poverty wherever they are. The implication of this - if we are serious about learning as a two-way process - is that countries such as the UK should be accepting volunteers from other countries. Perhaps mirroring the insider-outsider relationship described earlier, they might introduce ideas from their cultures that might help us to think through our own dilemmas and find creative solutions to our 'wicked issues': how to care for our older people, how to address homelessness, how to catalyse action and support livelihood initiatives in our economically marginalised cities and in the pockets of acute deprivation within our wealthy cities. Bringing outsiders to work with our insiders may trigger innovations. The universality of the SDG framework - despite its non-compulsory nature - may help to remind us that development can no longer be seen as a North to South process, and neither should volunteering.

\section{The 'leave no one behind' agenda}

Analysis of the shortcomings of the Millennium Development Goals (MDGs) has led to a shift in thinking, away from generic target setting which encouraged a focus on the 'low hanging fruit'. This meant that, in order to meet targets, those who were easier to reach and whose lives could be improved through concrete direct actions, were prioritised over the 'hard to reach' such as those who are multiply disadvantaged and excluded. Now, the intention is for the SDGs to focus on those who are greatest in need.

One issue has been the lack of disaggregated data that can give a clear picture of who benefits from aid, and who does not. This has led to the call for a 'data revolution' driven in particular by disability and minority groups who have argued that data that show how MDG targets have been met in terms of population average, can completely disguise the desperate situations of those who are most marginalised. For example, access to primary schooling in Bangladesh is over 90 per cent for the population as a whole and less than 10 per cent for disabled people (who make up around 20 per cent of the population). This is a critically important issue, and has also opened up another debate about the kinds of data that are needed to get a clear picture of the situation of the poorest and most marginalised, and how this data should be generated. The response of the UN and national governments to the call for a data revolution has been to set up high-level meetings of national statisticians to investigate how to generate disaggregated quantitative data.

This is needed but it is far from sufficient. We also need extensive qualitative data generated through participatory processes, which engage the poorest and most marginalised themselves. This will not only tell us what is happening, but also why and how it is happening, which is key to understanding - in context - what can bring about sustainable change. The Valuing Volunteering project showed how data of this sort could be generated on a large scale by embedded volunteers with research skills. This could be a major contribution to development in its own right. 
Working with the poorest and most marginalised also requires different sorts of interventions.

People in these groups face multiple interlocking and re-enforcing inequalities and these tend to be resilient to the sorts of programmatic interventions that development agencies offer. Providing good school curricula may result in a high-quality service for those who can afford to send their children to school, but does not address the exclusion from education of the poorest and most marginalised. A participatory approach that is constructed from ground level needs will be the best response, and volunteers (as illustrated by Lewis in this IDS Bulletin) are in a strong position to support this.

\section{Participation at all levels}

The emphasis on participation in the current post-2015 narrative is encouraging, but there is a great risk that it will not develop into clear policies and practice since for some it is no more than rhetoric, and others who subscribe to the ideas have no idea how to put them into practice. An explicit and significant area that is being articulated is 'participatory monitoring and accountability' (United Nations 2014). This has emerged as a strong response to civil society pressure, but also a response to Western governments' articulation of 'democratic governance'. One might argue cynically that this has as much to do with ensuring a stable enabling environment for Western business interests as it does any intrinsic belief in accountability. Many countries have implicitly rejected the idea of being held to account by their citizens - not least those with poor human rights records, and as a result we have already seen the 'accountability' language slip to 'review', reflecting a more managerial and less political and rights-based terminology.

Furthermore, when high-level politicians talk about participation they tend to refer to civil society engagement at the national level, or organised civil society representation in governance at the municipal level. Rarely do they refer to the participation of people in communities where development cooperation is intended to have impact, and where crucial knowledge resides about what works, for whom, and why. This represents a challenge and an opportunity for volunteering agencies. Their way of working through volunteers who live and work alongside partners puts them in a position to build relationships with people living in poverty and marginalisation, and to support and promote their participation in monitoring both local services and development aid. What becomes important is how volunteers build these relationships.
The explicit and extensive endorsement of volunteering as a strategy by the UN Secretary-General

The endorsement of volunteering in the SecretaryGeneral's synthesis report is a great opportunity for volunteering organisations. While on the one hand it can catapult volunteering centre stage within the UN system and give a boost to United Nations Volunteers (UNV) and other international and national volunteering organisations, there are also risks. As mentioned above, a finding of the Valuing Volunteering research was that the payment of highlevel stipends to volunteers distorts the volunteering landscape and has a negative impact on trust and social capital at community level (see Lewis, this IDS Bulletin). Greater visibility and funding for volunteering as a result of the UN endorsement could foster greater competition between volunteering agencies for volunteers, and further raise expectations among community members and potential volunteers through driving the perception of volunteering as an income generation activity rather than as a community mutual aid activity.

These trends highlight key challenges for volunteering into the future: the challenges of continuing austerity and a global capitalist development model that requires reduced public services; the challenges of meeting a global 'sustainable development' agenda in this climate; and the need to reach and work with the poorest and most marginalised who benefited least from the MDG era. What could be the appropriate model for 'volunteering for development' in the post-2015 decades?

\section{Where next for volunteering for development?}

The Valuing Volunteering research suggests that volunteers are well placed to respond to some of the big challenges of the new development landscape. In particular, the relational way in which volunteers work makes them better able to interact with those groups which are less easy to reach - the poorest and most marginalised. Evidence from the Participate initiative and elsewhere (Burns et al. 2013) showed that improvements in service delivery regularly did not benefit the poorest. This was because of how services were delivered and not because of what services were available. People were not being substantively reached by government or NGO staff because they were treated as inferior by professionals, they were not made aware of their entitlements, and money and resources were directed away from them as a result of corruption and nepotism, etc. There is potential here for volunteers who live amid communities and have better ground level networks, to better bridge this 
gap. International volunteers tend to have more time which can be put into relationship building; secondly, they are often more autonomous than formally employed NGO staff who operate within tight hierarchies. This may give them more leeway to mobilise networks to challenge injustices.

Analysis across the whole of the Valuing Volunteering research enabled us to draw out some of the specific characteristics of volunteering which enable development objectives to be achieved for the poorest and most marginalised. These are:

\section{Insider-outsider relations: VfD organisations} can actively stimulate the sorts of insider-outsider relationships (two-way relationships) that are likely to foster innovation at a local level. These are relationships that are productive because they are underpinned by the principles of mutual learning discussed earlier. A mutual learning approach to volunteering fosters 'relationships built on informality, the act of doing together and networked reciprocity' that Aked (this IDS Bulletin) identifies as significant for volunteering to lead to positive and sustainable change. Sustainability depends on local ownership and this is likely to come through the interaction of the new and the old rather than the imposition of outsider solutions.

Long-term programming: VfD organisations can construct long-term programmes which different volunteers can come into at different times. This runs strongly counter to the current re-emergence of short-term volunteering programmes. Evidence from both the Participate initiative and the Valuing Volunteering research showed that building longterm relationships and responding to bottom-up needs over time is the only way in which solutions will be appropriate, will become embedded and will avoid dependency. NGOs struggle with this as project funding is almost always short term, and it is often hard to get money for sustained work in one area.

\section{Participatory processes: VfD organisations can} root actions and interventions in deeply participatory processes, and develop a systemic understanding of change processes and power relationships within a locality. Volunteers of different types and provenance can be managed and support each other as part of a team, and supported to understand their particular contribution towards broader development outcomes. The idea of embedding a cadre of volunteer participatory researchers in volunteering country offices has a huge transformative potential, which is illustrated by the Valuing Volunteering research.
Taking a participatory approach to development - and to volunteering for development - means enabling dialogue within and between cultures. Building participatory research processes into aid organisations' programming and project cycles will facilitate:

- communicative spaces for exploring ideas and practices;

- potential for translation between ideas and practices across different cultures;

- begin to identify the possibilities of merging knowledges and articulating practices towards cooperation for a better world.

A way forward in this challenge is to work with 'epistemologies of the South' (Santos 2012), which means interrogating our assumptions and inquiring at both a conceptual level and at the level of social practice, in order to achieve 'mutual intelligibility' with our development partners. For Santos, this involves an act of translation between knowledges and practices. If achieved, it can result in co-creation. Chambers (2012: 72) also finds that 'if there is an open attitude from volunteers and the relevant methods for working are in place, there is potential not only for co-creation but for sharing and co-generating knowledges', what Santos (2012: 57) calls 'the ecology of knowledges'. This may, however, involve what Macdonald (2014) describes as 'decolonising the pedagogy of international experiential learning'. If, like Santos, we understand 'the South' not as a geographical area, but as a metaphor of the suffering caused by capitalism and colonialism at the global level, and a metaphor of resistance to these processes, this opens up possibilities for a deeper connection and for solidarities to develop between those who resist these processes but who have different positionalities - between insiders and outsiders.

\section{A focus on the poorest and most marginalised:}

The Participate research suggests that NGOs often don't get close to working with and improving the lives of the poorest and most marginalised. To do so requires simple things like working where they are - in more marginalised locations; embedding volunteers in the poorest communities, and training them to use tools that actually engage them.

Volunteers could be trained in participatory methods that generate collaboration and the kind of rich data that both makes visible the most marginalised groups and involves and enables these very groups in the analysis of what change needs to happen. 


\section{Conclusion: a post-colonial approach for the post-2015 landscape}

As volunteering for development broadens to include and to value local indigenous knowledge and forms of volunteering, the binaries of 'us and them' begin to be challenged. The SDGs will be universal, and recognise that there is poverty and marginalisation within the richer nations as well as in the poorer ones, and that solutions are interconnected. Post-colonial theory is useful here, as it questions the supremacy of the global North's worldview of itself as the civilising force and challenges binaries of North/South, us/ them (Gibson-Graham 1996). As such, it is particularly appropriate for exploring volunteering. Post-colonial thought understands knowledge as constructed and contested and mediated through power relations, and recognises the hegemonic tendencies of mainstream ('Northern') research methodologies and the privileging of 'Northern' forms of knowledge and constructions of meaning. Santos (2012) argues that we need to have a 'hermeneutics of suspicion', to be alert to the claims of Eurocentric theory - including critical theory - to be universally applicable, and to seek out 'epistemologies of the South' to understand the realities of the global South rather than impose on them frameworks devised to understand realities in Europe/the West/the North. His argument is that if we recognise the distance between these realities and embrace diverse epistemologies, we have a better chance of opening up possibilities of imagining a more equal world.

While the international volunteer may in some ways embody the colonial legacy and the neocolonial present, she may also collaborate in challenging and resisting it. To do this calls for a deeply reflexive and participatory approach, and in the context of development research, a post-colonial research ethics that encourages cross-cultural dialogue (Tikly and Bond 2013). This means understanding identities (of volunteers and of the people they relate with in their work) as 'multi-layered', and constructed by the relationships and positionings of each layer in specific historical context (Yuval-Davis 1999: 122; Baillie Smith 2013).
In practice, this places powerful demands on the international volunteer, to navigate values that are embedded in power relations. Burns (2015) describes this in terms of navigating 'the uncomfortable tension between an anti-colonial position which asserts that we should not be imposing Western values and norms on the South, and a values based position on issues such as patriarchy which asserts that deeply entrenched inequalities cannot be left unchallenged just because they represent cultural traditions and local social norms'. Is it possible to imagine development relationships which are simultaneously progressive and subject local power relationships to critical scrutiny without being colonial in their nature? How can we learn better to allow other perspectives to illuminate and bring a critique to our own practices? Perhaps, with the help of participatory approaches, the relational, informal volunteering space we have discussed here is a space in which such reflection is possible.

The Valuing Volunteering research discussed in this IDS Bulletin is only one attempt to better understand the complexity of volunteering for development. Further research is needed that focuses on the perspectives and experiences of host organisations, of community volunteers and national volunteers. There is some emerging work in this area that needs to be built on (Sin 2010). Here, we have argued for the need to co-create development solutions through participatory processes, and that volunteers are well placed to promote or facilitate such processes. A better understanding of indigenous informal volunteering will be important, and also greater reflection on how 'outsider' volunteers can support community work and do no harm.

Listening, translating and integrating the epistemologies of the South may help in this endeavour. The research does seem to endorse volunteering as having a unique contribution to make to development, and there is some evidence that volunteering that takes a participatory approach can represent a beacon for collectivism in an increasingly individualist world. The bottom-up development approach that is characteristic of the best of volunteering can accentuate the power of collective action, in contrast to a specialist service delivery approach which reinforces the emphasis on individual consumption and a framing of rights which leads to dependency. 


\section{Notes}

1 See statement: www.theguardian.com/uk/2007/ aug/14/students.charitablegiving (accessed January 2013).

\section{References}

Andres, L. and Round, J. (2015) 'The Role of "Persistent Resilience" Within Everyday Life and Polity: Households Coping with Marginality Within the "Big Society", Environment and Planning A 47.3: 676-90

Anheier, H. and Salamon, L. (2001) Volunteering in Cross-national Perspective: Initial Comparisons, Civil Society Working Paper 10, London: London School of Economics

Baillie Smith, M. (2013) 'Public Imaginaries of Development and Complex Subjectivities: The Challenge for Development Studies', Canadian Fournal of Development Studies/Revue Canadienne d'études du Développement 34: 400-15

Baillie Smith, M. and Laurie, N. (2011) 'International Volunteering and Development: Global Citizenship and Neoliberal Professionalisation Today', Transactions of the Institute of British Geographers 36.4: 545-59

Banks, N.; Hulme, D. and Edwards, M. (2015) 'NGOs, States, and Donors Revisited: Still Too Close for Comfort?', World Development 66: 707-18

Burns, D. (2015) The Power of Connecting Insider and Outsider Relationships, IDS blog, 29 April, www.ids.ac.uk/opinion/the-power-of-connectinginsider-and-outsider-relationships (accessed 17 July 2015)

Burns, D.; Howard, J.; Lopez Franco, E.; Shahrokh, T. and Wheeler, J. (2013) Work With Us: How People and Organisations can Catalyse Sustainable Change, Brighton: IDS, www.ids.ac.uk/publication/work-withus-how-people-and-organisations-can-catalysesustainable-change (accessed 16 July 2015)

Burns, D.; Picken, A.; Hacker, E.; Aked, J.; Turner, K.; Lewis, S. and Lopez Franco, E. (2015) The Role of Volunteering in Sustainable Development, Brighton and London: IDS and VSO

Chambers, R. (2012) 'Sharing and Co-generating Knowledges: Reflections on Experiences with PRA1 and CLTS2', IDS Bulletin 43.3: 71-87

Cornwall, A. (2000) Beneficiary, Consumer, Citizen: Perspectives on Participation for Poverty Reduction, Stockholm: Sida

Cornwall, A. and Gaventa, J. (2000) 'From Users and Choosers to Makers and Shapers Repositioning Participation in Social Policy', IDS Bulletin 31.4: 50-62

Devereux, P. (2008) 'International Volunteering for Development and Sustainability: Outdated Paternalism or a Radical Response to Globalisation?', Development in Practice 18.3: 357-70

Escobar, A. (2011) Encountering Development: The Making and Unmaking of the Third World, Princeton NJ: Princeton University Press

Esteva, G. (2014) 'Commoning in the New Society', Community Development Fournal 49 (suppl 1): i144-159

Gibson-Graham, J.K. (1996) The End of Capitalism (As We Knew It): A Feminist Critique of Political Economy, Oxford: Blackwell

Henderson, V. (2009) 'Citizenship in the Line of Fire: Protective Accompaniment, Proxy Citizenship, and Pathways for Transnational Solidarity in Guatemala', Annals of the Association of American Geographers 99.5: 969-76

Heron, B. (2007) Desire for Development: Whiteness, Gender, and the Helping Imperative, Waterloo ON: Wilfrid Laurier University Press

Hopkins, P.; Olson, E.; Baillie Smith, M. and Laurie, N. (2015) 'Transitions to Religious Adulthood: Relational Geographies of Youth, Religion and International Volunteering', Transactions of the Institute of British Geographers 40.3: 387-98

Howard, J.; Lewis, S. and Burns, D. (2015) 'VSO Participation and Governance Review', unpublished report

Jefferess, D. (2012) 'Unsettling Cosmopolitanism: Global Citizenship and the Cultural Politics of Benevolence', in V. de Oliveira Andreotti and L.M.T.M. de Souza (eds), Postcolonial Perspectives on Global Citizenship Education, London: Routledge

Jones, A. (2008) 'The Rise of Global Work',

Transactions of the Institute for British Geographers 33.1: $12-26$

Lopez Franco, E. and Shahrokh, T. (2012) 'Literature Review to Inform the Design of Valuing Volunteering', unpublished, Brighton: IDS

Lough, B.J. and Matthew, L. (2013) Measuring and Conveying the Added Value of International Volunteering, Forum Discussion Paper, www.france-volontaires. org/IMG/pdf/ivco2013_measuring_and_ conveying_the_added_value_of_international_ volunteering_lough.pdf (accessed 4 August 2015)

Lough, B.J.; McBride, A.M.; Sherraden, M.S. and O'Hara, K. (2011) 'Capacity Building Contributions of Short-term International Volunteers', Fournal of Community Practice 19.2: 120-37

Macdonald, K. (2014) 'Decolonising Pedagogies: An Exploration of Learning with Students Volunteering Abroad', in R. Tiessen and 
R. Huish (eds), Globetrotting or Global Citizenship?: Perils and Potential of International Experiential Learning, Toronto: University of Toronto Press

Mostafanezhad, M. (2014) 'Volunteer Tourism and the Popular Humanitarian Gaze', Geoforum 54: 111-18

Perez, L. and Martinez, J. (2008) 'Community Health Workers: Social Justice and Policy Advocates for Community Health and Wellbeing', American fournal of Public Health 98: 11-14

Perold, H.; Graham, L.; Mazembo Mavungu, E.; Cronin, K.; Muchemwa, L. and Lough, B. (2013) 'The Colonial Legacy of International Voluntary Service', Community Development fournal 48.2: 179-96 Santos, B. de Souza (2012) 'Public Sphere and Epistemologies of the South', Africa Development 37.1: 43-67

Said, E. (1978) Orientalism, New York: Vintage Simpson, K. (2004) “Doing Development”: The Gap Year, Volunteer-Tourists and a Popular Practice of Development', Fournal of International Development 16.5: 681-92
Sin, H.L. (2010) 'Who are we Responsible to? Locals' Tales of Volunteer Tourism', Geoforum 41: 983-92 Taylor, M. (2011) Public Policy in the Community: Public Policy and Politics, 2nd ed., Hampshire: Palgrave Macmillan

Tikly, L. and Bond, T. (2013) 'Towards a Postcolonial Research Ethics in Comparative and International Education', Compare: A Journal of Comparative and International Education 43.4: 422-42

United Nations (2014) https://sustainabledevelopment.un.org/content/ documents/4488ParticipatoryMonitoring_8_ july_side_event_summary_final.pdf (accessed 16 July 2015)

Wehbi, S.; Elin, L. and El-Lahib, Y. (2010) 'Neo-colonial Discourse and Disability: The Case of Canadian International Development NGOs', Community Development Fournal 45.4: 404-22

Yuval-Davis, N. (1999) 'The "Multi-layered Citizen"', International Feminist fournal of Politics 1.1: 119-36 